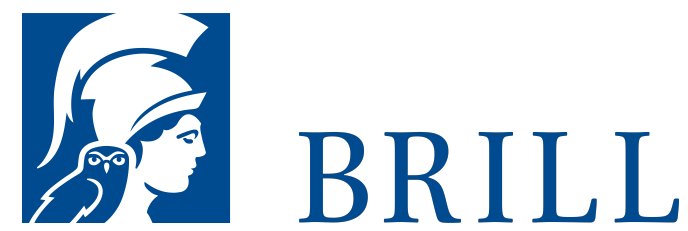

\title{
Fihrist-i nushkhahā-yi khațti-yi Fārsi-yi Kitābkhāna-yi Markazi-yi Dānishgāh-i Punjāb Lāhūr (Pākistān). Volume 2
}

\author{
Majmū'ahā-yi Āzād, Pīrzādah, Shīrānī, Kayfī wa 'Umūmī
}

Author: 'Ārif Nūshāhī

Punjab University Library in Lahore, Pakistan, formerly College Library Punjab University in 1873, acquired its present name when the college gained university status in 1882 . Punjab University has some 50 affiliated libraries in various departments, colleges and institutes, with Punjab University Library as its major, 'central' library. This library possesses the largest collection of manuscripts in Pakistan and in 2007 their number had reached $\mathbf{1 4 . 4 8 2}$ titles in Persian, Arabic and Urdu. Besides a general section comprising manuscripts purchased from or donated by ordinary citizens, the manuscript department contains seven subcollections, acquired from prominent collectors: Āzād, Pīrzāda, Kayfî, Woolner, Shīrānī, Maḥbūb 'Alam, and Āzar. The present two-volume catalogue, prepared by the well-known Pakistani specialist of Islamic manuscripts, 'Ārif Nawshāhī, and his collaborators, describes manuscripts in the general section and in four of the seven subcollections. Only manuscripts that were thusfar not or insufficiently catalogued are recorded, with work on the Shīrānī collection still being incomplete.

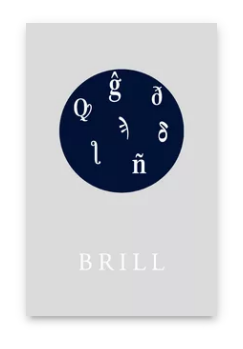

Language:

Persian

Subjects:

General, Middle

East and Islamic

Studies, Religion

in Asia,

Religious

Studies

Publisher: Brill

Series:

Persian E-Books

Miras Maktoob

E-Book (PDF)

Released online:

29 Jun 2020

ISBN: 978-90-

04-40779-4

List price

USD $\$ 75.00$ 
For more information see brill.com

Order information: Order online at brill.com +44330 333 0049 | customerservices@brill.com Submission information: brill.com/authors

Titles published by Brill | Fink, Brill | mentis or Brill | Schöningh: +49(o)715413279216| brill@brocom.de 